\title{
Travessias: espaços da casa e vidas negras
}

\section{Susana Fuentes ${ }^{1}$}

Resumo: Este estudo nasce a partir da leitura e meu processo de tradução para o inglês do conto "Cândido Abdellah Jr., de Cristiane Sobral (2021). Aqui, pretendo pensar o espaço da casa como um espaço do bem e do mal, notando aspectos de intimidade e identidades no conto. Problemas da branquitude, a imaginação literária do branco em seus jogos de expulsar da intimidade o negro, ou a criança negra, num gesto de tentar apagar singularidades e diferenças, na afirmação de uma superioridade que reassegura territórios. Preconceitos e castigos que têm sido uma constante na história do imaginário social brasileiro permeiam o conto de Sobral, mas no movimento de lançar pistas, a autora surpreende os leitores com novos caminhos para seu protagonista, o Cândido. Em perspectiva comparada e intercultural, a tradução foi um caminho de diálogo com temporalidades de uma diáspora, tempos e vozes que emergem quando se escutam os potenciais ruídos do texto. Palavras-chave: Ser negro. Identidades. Tradução intercultural.

\section{Vidas negras, identidades}

o conto “Cândido Abdellah Jr.", de Cristiane Sobral, de seu novo
livro Amar antes que amanheça (2021), um menino de três anos que perambulava pelas ruas é trazido para o interior da casa de pais brancos que resolvem adotá-lo informalmente. Assim começa a história de Cândido, narrada em primeira pessoa, pelo menino já crescido. Nessa casa, a que ele retorna adulto, num jogo de pistas e despistes na trama do conto, o quarto era o único lugar de paz na casa, mas também onde ele mais apanhou do pai (SOBRAL, 2021, p.102).

Homi Bhabha, em Locais da Cultura (1998), escreve sobre "os recessos do espaço doméstico", como eles

1 Doutora em Literatura Comparada pela UERJ, onde desenvolveu pesquisa de Pós-Doutorado (Bolsa CAPES/ FAPERJ). 
[...] tornam-se os lugares das invasões mais intrincadas da história. Nesse deslocamento, as fronteiras entre casa e mundo se confundem e, estranhamente, o privado e o público tornam-se parte um do outro, forçando sobre nós uma visão que é tão dividida quanto desnorteadora (BHABHA, 1998, p.30).

Darcy Ribeiro escreve em O Povo Brasileiro:

As atuais classes dominantes brasileiras, feitas de filhos e netos dos antigos senhores de escravos, guardam, diante do negro, a mesma atitude de desprezo vil. Para seus pais, o negro escravo, o forro, bem como o mulato, eram mera força energética, como um saco de carvão, que desgastado era substituído facilmente por outro que se comprava. [...] A nação brasileira, comandada por gente dessa mentalidade, nunca fez nada pela massa negra que a construíra. Negou-lhe a posse de qualquer pedaço de terra para viver e cultivar, de escolas em que pudesse educar seus filhos, e de qualquer ordem de assistência. Só lhes deu, sobejamente, discriminação e repressão (RIBEIRO, 2014, p.169).

No conto de Cristiane Sobral, sob a perspectiva do narrador negro, revela-se como era difícil criar referências identitárias numa família que não tinha sido preparada para adotar um menino negro: "Aos poucos fui percebendo que meus pais deveriam ter sido preparados para adotar uma criança negra de forma a saber lidar com as questões raciais" (SOBRAL, 2021, p. 98). O mal aparece na intimidade de uma família que, além de não trazer referências para a construção de identidades negras, não reconhece a existência do racismo e falha como porto seguro de uma escuta dos desafios que o menino terá que enfrentar num extrato social onde ele é o único negro: 
Eles não me consideram uma pessoa negra, na minha vida foi como se eu tivesse sido criado como "o filho branco que é escuro", por apenas um detalhe, porque segundo eles todos éramos iguais, filhos de Deus. O grupo familiar nem ao menos aceitava a existência do racismo, defendiam, acima de tudo, a supremacia do princípio cristão da igualdade (SOBRAL, 2021, p. 98).

Em seu contar a história, há o pai, a mãe, senhor e senhora Abdellah, assim como os irmãos brancos, a babá negra, entre os vários educadores que se ocuparam dele e trabalhavam por dinheiro na casa abastada: "As cuidadoras que ajudaram a me criar trabalhavam por dinheiro, assim como os demais funcionários da casa, os professores também” (SOBRAL, 2021, p.97). Mais adiante, no conto, ouvimos de Cândido pistas que surgem no seu retorno a casa e no espaço da terapia, e logo sabemos que a analista é branca. Ela é doutora Gabriela e ele é doutor Cândido (tornou-se médico, neurocirurgião bem sucedido), e a terapia será um espaço o qual ele descobre ser sagrado em sua confidencialidade; e do ódio inicial nas sessões por ela ser branca, algo se transforma e ele segue com as sessões. Com a terapeuta, há uma escuta, pois, pela primeira vez alguém não diz, como costumava ouvir do pai: "isso não seria coisa da sua cabeça?" (SOBRAL, 2021, p.98) ou "reze, peça perdão a Deus. Sabe o que é isso? É ingratidão!" (SOBRAL, 2021, p.98). E a terapia será o espaço para ele se descobrir no ódio que sente dos pais, ódio entranhado em sua memória da casa em meio a tudo o que ouviu lá. Ódio que invade o sonho, e o retorno a essa casa de sua infância, onde a única peça que falta é o seu espelho, seu espelho negro, o quadro de Bob Marley na parede de seu quarto (SOBRAL, 2021, p.102).

\section{Inscrições na cidade, o bem e o mal}

Personagens brancas e negras trafegam pelos contos de Amar antes que amanheça. O conto "223784", outro conto de Cristiane Sobral do 
mesmo livro, revela a ternura que falta numa família como a de Cândido sem referências da negritude. Na casa da outra família, o leitor se depara com a ternura que o menino Cândido nunca sentiu. A menina Jurema tem o olhar de seu pai a revelar sua pretitude. O casamento inter-racial - mãe branca, pai negro -

é a união que construíram juntos, longe de suas respectivas famílias e espaço de afirmação de identidades pretas. Cenas de um lugar de ternura na cidade, sem apagamentos, onde nasce a inscrição de suas memórias e linhagens no encontro entre pai e filha, singularidades que conversam entre as diferentes gerações. Na conversa da menina com o pai, ouvimos seu pensamento, aprendemos o amor do pai pela filha:

Jurema, a razão dos seus dias na Terra, estava ali de carne, osso e pele ainda mais escura que a dele, parecia talhada como alguma escultura egípcia em seu pretume irretocável. Da mãe, trouxera os olhos de mel, enormes, como faróis reluzentes, o corpo esguio e o tom morno na voz (SOBRAL, 2021, p.121).

Aqui lemos a inscrição no texto de Cristiane Sobral, ficcionista e poeta, na sua participação na construção de uma cidade onde as vozes negras, a peles negras habitam as casas, percorrem as ruas, os espaços da cidade. E trazem à tona os escurecimentos, além da ternura e força. E revela o seu avesso: o que falta, o que não há num texto que naturalize as diferenças, num país que esconde a sua cor, em séculos de um pensamento hegemônico.

Contra os apagamentos, a luta não está ganha, e o pai no conto sabe disso, e alerta a menina:

- Pretinha do pai, você é o meu orgulho, filha amada, Deus que te abençoe. Vá na proteção de São Jorge e de Nossa Senhora Aparecida e não se esqueça de tudo em que acreditamos, da nossa fé nos orixás. Lembre- 
se, onde estiver, da resistência do nosso povo [...] (SOBRAL, 2021, p.122)

E ouvimos a frase que ela repete e que aprendeu com seu pai, Mazinho: “ - Já sei, pai, sou negra, sou mulher, com muito orgulho. Não serei conivente com o preconceito nem com a violência, sou capaz e sempre lutarei pelos meus direitos!” (SOBRAL, 2021, p.122)

É evidente o contraste com espaço da casa de Cândido, na sua casa a falta das referências religiosas das matrizes africanas e de um povo em diáspora. Somos "guerreiros" e "vitoriosos", diz Mazinho para a filha Jurema no conto "223784", os números que servirão de aposta no jogo do bicho e que se revelam parte do tecido das relações ancestrais. Na casa dos Abdellah, "pai e mãe espíritas que faziam o evangelho e depois discutiam até dormir" (SOBRAL, 2021, p.97), não há olhos que enxerguem a cor do filho, nem há escuta para o que ele sente, se na casa nem acreditavam em racismo, quanto mais nomear apagamentos ao longo de sua infância e juventude; tudo seria coisa da sua cabeça, como vimos na fala de seu pai. E quando Cândido volta à casa de sua infância, e olha para a parede de seu antigo quarto, além do quadro de Bob Marley, outra coisa não estava na parede branca: o seu sangue. O sangue das surras que levou, a mancha na parede de cada vez que apanhou do pai.

Noto que, em outro conto de Amar antes que amanheça, "Amor de algodão", há paredes manchadas de sangue, mas paredes não de um quarto, e sim, das celas de um presídio. E aí temos a violência de uma prisão, algo em comum com as paredes do quarto de Cândido. Eis o amor da família "que amava com bens materiais e discutível bondade" (SOBRAL, 2021, p.97), nas ironias cortantes do narrador desde as primeiras palavras do conto "Cândido Abdellah Jr." Cândido não conheceu, nesse espaço da casa, o que era amor. Mas, no conto "Amor de algodão", acompanhando os passos de uma mulher trans, Amanda, sabemos que ela "desejava ser amada desesperadamente, desejava ser amado desesperadamente o homem 
nela, a mulher nele" (SOBRAL, 2021, p. 67). E, quando acompanha a amiga nas visitas ao presídio, vê "que havia amor naquele lugar horrível, talvez pelo desespero, a pulsão de morte, a agressividade impressa nas paredes manchadas de sangue" (SOBRAL, 2021, p. 67), eis improvável do amor, o sexo, o par amoroso, na violência. Ecos do único contato que Cândido terá com os pais, quando em seu ódio revelado no sonho, verte não o seu sangue, mas o deles: "Percebi que, ao matar meus pais, finalmente tocava e era tocado, renascia de um jeito inesperado" (SOBRAL, 2021, p.103). O sangue que Cândido quer verter dos pais, neste sangue ou sonho, ele tem uma ereção e bate mais e mais: "Aquele gesto inesperado me trouxe um prazer, uma ereção e uma imensa alegria que eu nunca havia experimentado na vida” (SOBRAL, 2021, p.103).

Mas, quando ele é garoto, era dele o sangue, entre quatro paredes, o menino Cândido que apanhava, vulnerável. E também Amanda, do conto "Amor de algodão", sabe do espaço da intimidade o seu perigo: as "mulheres trans são assassinadas e sofrem violências inimagináveis entre quatro paredes" (SOBRAL, 2021, p. 69). Ela vive exposta ao preconceito do outro. Entretanto, na jaula, na prisão, no espaço que se mostra como é, Amanda sabia negociar: "Na jaula, tudo é comércio" (SOBRAL, 2021, p.69). Na prisão é onde se sabe que a vida e o amor têm que ser negociados. Mas e quando não se sabe, quando o espaço (da casa) promete amor e traz o ódio escondido? Como no quarto de Cândido, que ainda irá aprender a falar sobre isso, e sobre o próprio ódio que nunca viera à tona; ele, menino, apanhava em seu quarto em silêncio. Sua casa, o retrato estranhamente familiar de nossa sociedade, de um racismo que não queria se dar a ver e de uma elite brasileira que se diz superior e benevolente. Lembremos com Darcy Ribeiro:

$\mathrm{O}$ aspecto mais perverso do racismo assimilacionista é que ele dá de si uma imagem de maior sociabilidade, quando, de fato, desarma o negro para lutar contra a 
pobreza que lhe é imposta, e dissimula as condições de terrível violência a que é submetido. [...]Prevalece, em todo o Brasil, uma expectativa assimilacionista, que leva os brasileiros a supor e desejar que os negros desapareçam pela branquização progressiva. (RIBEIRO, 2014, p. 173)

Ora, o mal-estar de um racismo estrutural que, no Brasil, aparece numa tensão que se quer disfarçada, esse mal-estar clama por mudança, por ver o conflito exposto. Desse perigo de não ver o inimigo, Darcy Ribeiro escreveu como o aspecto perverso do racismo assimilacionista. E, no avesso da dissimulação da violência, evidencia o genocídio negro:

O povo-nação não surge no Brasil da evolução de formas anteriores de sociabilidade, em que grupos humanos se estruturam em classes opostas, mas se conjugam para atender às suas necessidades de sobrevivência e progresso. Surge, isto sim, da concentração de uma força de trabalho escrava, recrutada para servir a propósitos mercantis alheios a ela, através de processos tão violentos de ordenação e repressão que constituíram, de fato, um continuado genocídio e um etnocídio implacável. (RIBEIRO, 2014, p.15)

Considerando as sociedades modernas a partir do século XVII, quando a semente de uma ambição ilimitada levará à exploração crescente da força de trabalho nos séculos XVIII e XIX, limitando o descanso e os prazeres, nos é possível vislumbrar a velocidade, a eficiência de gestos rápidos e uniformes contra o ritmo natural individual. Ora, o choque entre duas culturas, uma, dita Ocidental, buscando, contra o ritmo natural, a eficiência e, a outra, não dita, maldita aos seus olhos e fora do compasso, vai gerar um grande complexo de imagens, desejos e silêncios, cujos rastros figuram em textos literários. O processo de controle sobre o corpo do negro, 
de deformação de seus gestos e fala na literatura produzida por brancos, delimitando fronteiras entre o civilizado e o selvagem, traz o bem estar de se percorrer o outro lado da fronteira sem despir-se de sua "superioridade" ética e moral. Lembremos da peça $O$ demônio familiar, de José de Alencar, comédia em quatro atos que estreia em novembro de 1857 no Teatro Ginásio Dramático: o menino negro, um servo, aparece como o mal dentro da família. E a "abolição da escravatura” será uma forma de expulsar dos lares esse mal e se livrar do menino. A comédia realista, de acordo com João Roberto Faria, "transpunha para o palco a seriedade burguesa, a preocupação com as instituições e a moral" (FARIA, 1987, p.18). De fato, Décio de Almeida Prado afirma no prefácio ao livro de João Roberto Faria José de Alencar e o teatro (1987) que Alencar quer modernizar o teatro brasileiro e deseja "reformar ao mesmo tempo a sociedade brasileira, livrando-a de suas taras e contradições ao reafirmar no palco os valores ideais da moral burguesa" (PRADO, 1987 apud FARIA, 1987, p.xiv). Desde logo, cabe observar que tal desejo de cura fica patente nas palavras que finalizam o espetáculo e se despedem do espectador - é Eduardo, o jovem senhor da casa, quem convida:

E agora, meus amigos, façamos votos para que o demônio familiar das nossas casas desapareça um dia, deixando o nosso lar doméstico protegido por Deus e por esses anjos tutelares que, sob as formas de mães, de esposas e de irmãs, velarão sobre a felicidade de nossos filhos!... (ALENCAR, 1977, p. 98)

Como chefe de família, Eduardo, na peça de José de Alencar, tem o poder de decidir sobre o espaço de cada um na casa. E mesmo de definir quem pertence ao domínio familiar. E, ironicamente, tem o poder de exercer "um dos mais belos direitos que tem o homem na nossa sociedade" - "o direito de dar a liberdade" (ALENCAR, 1977, p. 98). A alforria, aí, é quase uma imagem da atitude brasileira de descaso no que se anuncia um 
bem. Na verdade, eu diria da peça de Alencar, a questão não é ver Pedro livre, mas ver-se livre de Pedro.

A história de resistência dos escravizados ao longo do século XIX, e dos quilombos e revoltas organizadas contra a escravidão passam ao largo da peça. Significativo que surja a imagem de um "demônio familiar" - identificado no seio da família, é percebido como um mal onde se concentrariam todas as culpas; uma vez excluído, a harmonia se instaura. Aqui, a fala de Eduardo:

Os antigos acreditavam que toda a casa era habitada por um demônio familiar, do qual dependia o sossego e a tranquilidade das pessoas que nela viviam. Nós, os brasileiros, realizamos infelizmente esta crença; temos no nosso lar doméstico esse demônio familiar. Quantas vezes não partilha conosco as carícias de nossas mães, os folguedos de nossos irmãos e uma parte das afeições da família! Mas vem um dia, como hoje, em que ele na sua ignorância ou na sua malícia, perturba a paz doméstica; e faz do amor, da amizade, da reputação, de todos esses objetos santos, um jogo de criança. Este demônio familiar de nossas casas, que todos conhecemos, ei-lo. (ALENCAR, 1977, p. 98).

Eis aí a velha fórmula do imaginário sobre o negro: o ignorante, infantil, ou o demoníaco, monstruoso. E cabe ao branco conduzi-lo ou expulsá-lo. Eduardo tenta os dois: "Eu o corrijo, fazendo do autômato um homem; restituo-o à sociedade, porém expulso-o do seio de minha família e fecho-lhe para sempre a porta de minha casa" (ALENCAR, 1977, p. 98).

No conto de Cristiane Sobral, o pai branco acolhe a criança negra, mas quer que fique do lado de fora o seu "sangue negro que não presta" (SOBRAL, 2021, p.99). Acredita que o filho deveria agir como um branco, e até durante as surras diz: "Hoje você vai apanhar pra aprender a ser branco" (SOBRAL, 2021, p.99). O mesmo pai que, no início do conto, diz 
a frase que se repetirá na memória - acolhemos o seu corpo miúdo, seus pais costumavam dizer (SOBRAL, 2021, p.97). Lembrando Nietzsche, fica evidente "a felicidade da 'pequena superioridade' que acompanha todo ato de beneficiar, servir, ajudar, distinguir..” (NIETZSCHE, 1998, p.124)

$\mathrm{Na}$ peça $\mathrm{O}$ demônio familiar, acima mencionada (ALENCAR, 1977), o senhor da casa se faz duplamente "generoso". Por um lado, concede a liberdade, gesto nobilíssimo, alegria suprema e, por outro, corrige, acredita tornar, assim, o homem Pedro bom, dócil... E ainda se faz protetor da santidade do lar, assegura o "bem-estar" das mulheres da casa - ou as aprisiona, melhor seria dizer, sob a forma de "anjos tutelares". É deste modo que, num único gesto, o senhor cria toda uma nova esfera de distanciamento à sua volta, reorganiza, sob outra forma, o esquema ideal, em torno de garantias e certezas.

Interessa ver aí o grito contra os movimentos de apagamento, tornados visíveis e desnaturalizados no conto de Cristiane Sobral. O pai adotivo quer educar a criança, e traz o menino para dentro da família. Num movimento ambíguo, no entanto, às custas do apagamento da identidade da criança - e até com sessões para afastar os carmas de fracassos de seus antepassados:

a família fez questão de que eu frequentasse os atendimentos para reprogramação genética e também visando evitar fracassos cármicos dos meus antepassados pretos (SOBRAL, 2021, p.104).

E Cândido trabalhará sozinho para construir suas identidades. O seu "espelho negro", seu quadro de Bob Marley na parede do quarto, e as pessoas notáveis a que ele alude no conto, serão suas referências para sobreviver e lutar. 
Homi Bhabha escreve: "o trabalho fronteiriço da cultura exige um encontro com 'o novo' que não seja parte do continuum de passado e presente. Ele cria uma ideia do novo como ato insurgente de tradução cultural" (BHABHA, 1998, p.27). E aponta a importância de renovar o passado, 'refigurando-o como um 'entre-lugar' contingente, que inova e interrompe a atuação do presente. $O$ 'passado-presente' torna-se parte da necessidade, e não da nostalgia, de viver" (BHABHA, 1998, p.27).

No conto de Cristiane, nesse Cândido sofrendo no espaço da intimidade o preconceito e dor que se repete há séculos, e mesmo assumindo o comportamento do menino bem comportado que queriam dele, há uma transgressão e uma resposta que interrompe, para pensar com Homi Bhaba, essa atuação do presente. O conto foi apresentado pela primeira vez aos leitores na Oficina do SELCS Brazilian Translation Club, uma parceria da Universidade de Londres com o Escritório Modelo de Tradução Ana Cristina Cesar/Uerj e a Festa Literária das Periferias. Para essa Oficina, coube a mim a tradução do conto para o inglês, pensando a tradução intercultural, a partir dos anos de pesquisa junto ao Centro de Estudos Interculturais do Escritório Modelo de Tradução Ana Cristina Cesar, coordenado por Maria Aparecida Andrade Salgueiro. Na Oficina, na conversa com Cristiane Sobral, a autora revelou que quis fugir do script que se espera das vidas negras, de virar o marginal, assassino, parte de um imaginário de uma branquitude. O nome Cândido, lembrou Ana Claudia Suriani, em sua apresentação teórica na Oficina, vem do branco, alvo, e apontou que é o mesmo nome do capataz no famoso conto de Machado de Assis, "Pai contra mãe" - Machado em sua ironia de apontar as tensões entre nome e personagem.

A narrativa de Cândido inicia com o menino que é nascido de pai e mãe desconhecidos. Antes de saber de sua adoção, é isso que aprendemos, sua origem, uma fenda. O corpo de uma história que não nos é dado saber, 
mas, ao mesmo tempo, o corpo de uma história que conhecemos, apesar das tentativas de apagamentos, de embranquecimentos da história, ela grita cada vez mais, a travessia da diáspora, as migrações, as violências do partir sem trazer nada consigo. Traz, no entanto, a língua, as relíquias da cultura de uma ancestralidade que precisará de chão, tempo e luta para se reunir em vestígios de tantos náufragos que se revelam combatentes.

Ele, Cândido, apesar do nome, é mancha, resto, resquício, corpo que vinga chegar à outra margem. E convoquemos o tempo dessa escuta, como leitores no caminho para o outro, façamos a pergunta: esse menino quantas vezes ouviu seu nome? Ele ao longo dos anos a ouvir candura, nesse corresponder ao alvo, puro, cândido, ele cresce em contornos da palavra de outros que o nomeiam. Mas há algo nele que quer dizer, e deseja operar diferenças e dizer o próprio movimento, arriscar as próprias palavras. E irá buscar referências na construção de identidades já em outra travessia, não mais abandono, mas de esperança e luta.

Não apenas crescer com esse nome, mas ouvir dos pais adotivos a frase que podemos imaginar, como se dissessem, a cada vez, acolhemos $o$ seu corpo miúdo (Cf. SOBRAL, 2021, p.97). Ora, se paramos para ouvir na repetição, essa frase é um peso muito grande para um menino. No tempo da tradução, no tráfego de sons, ruídos, gestos, ficou cada vez mais em evidência que havia no conto frases que se repetem na cabeça de Cândido. E essa frase aparece no primeiro parágrafo e a conhecemos assim: "Os meus pais costumavam dizer que acolheram meu corpo miúdo [...]” (SOBRAL, 2021, p.97). No movimento de tradução, ao buscar a palavra, apareceu o arranhado desse ato, sua passividade, e busquei received como acolher, termo que aparece no contexto de artigos originais sobre travessias, imigrantes, em língua inglesa - e há a passividade do gesto na palavra e, ao mesmo tempo, um ato que se anuncia benfazejo. Assim, "We received your tiny body, my parents used to say", e aqui ainda inverti a ordem da frase, para que ela ficasse em evidência. É possível notar que o objetivo 
dessa escolha foi destacar o tempo de escuta do menino; ele ouvindo o dito pelos pais. E essa seria a frase que iria me nortear na tradução, ou melhor, a frase que me conectou no tempo do afeto, da ferida, para que eu pudesse seguir na escuta desse menino, e desse narrador adulto que mais à frente irá nos surpreender - no inquietante e perturbador jogo de pistas e despistes de Cristiane Sobral, num mover-se dialético entre o bem e o mal. Frase que diz acolher e, ao mesmo tempo, aponta o abandono. E aponta o corpo miúdo (enquanto os meninos, e as meninas gostariam de ouvir de sua força, e desejam ser fortes). Foi importante notar o arranhado dessa frase no texto, esse acolher como um bem que se grita aos quatro ventos, e, mais terrível, ao próprio menino que recebeu essa acolhida. A ênfase estaria no gesto, como somos bons. Porém, acolher seria uma ação, e não um dizer. Entre o bem e o mal, esse o resíduo que a frase me trouxe no movimento de tradução, nesse demorar-se, ver o que resta, vestígios, rasgos do que se conta, e uma inquietude nesse acolher.

Esse devir da língua, a tradução do mundo em constante devir. Os ruídos da língua. Os rumores na casa. A tarefa do tradutor às voltas com tempos diversos que se chocam e resíduos e pregas, não mais a casca que se encaixa em torno da fruta. Agora cacos, impossibilidades, e lembrar com Benjamin o que sobrevive, esse sobreviver na língua, despedir-se. Na tarefa do tradutor ou "tarefa-renúncia do tradutor", como no título da tradução do ensaio de Benjamin por Susana Kampff Lages:

a relação do conteúdo com a língua é completamente diversa no original e na tradução. Pois, se no original eles formam uma certa unidade, como a casca com o fruto, na tradução, a língua recobre seu conteúdo em amplas pregas, como um manto real. Pois ela significa uma língua mais elevada do que ela própria é, permanecendo com isso inadequada a seu próprio conteúdo - grandiosa e estranha. (BENJAMIN, 2008, p. 73-74) 
E aí, minha abertura para entrar na corrente do conto: perceber a dor. Ela que virá mais adiante no conto, em vários momentos, e o mais pungente: quando ele apanhava em seu quarto. Adulto, o Cândido retorna a casa e não vê a mancha do seu sangue nas paredes: "Procurei vestígios do meu sangue na parede, não havia, claro" (SOBRAL, 2021, p.102).

Podemos pensar as várias camadas de sangue, e o sangue que não está no quarto. E me pergunto se o leitor vê o sangue na parede ou não. E, na tradução, nesse movimento de ler na escuta, e nesse pensar intercultural, se fazer perguntas, nesse movimento de escuta, escavação, você encontra o sangue, você trafega num lugar com todos esses ruídos. E ouve. E há um naufrágio. É aí que começamos. Essa possibilidade de escutar o texto no registro dos que não têm casa, uma memória coletiva dos que foram empurrados para as margens.

No conto de Cristiane Sobral, a cortante ironia a dizer as coisas do dia a dia, e trazer lado a lado bem e mal. E Cândido, em sua busca por identidades, no processo de análise outro espaço se revela, e também o ódio, a fúria que não mais se esconde, mas estava perdida, e é preciso resgatar. Aparece no sonho - e é nomeado na sessão de terapia que Cândido frequenta.

O espaço do quarto, no conto de Sobral, e, depois, o espaço da análise: no consultório se diz o impronunciável, e se revela o incômodo, submerge o que estava quieto, os restos, na travessia. E neste falar, na narrativa, novos significantes. Cândido em seu desejo de identidades, de se reescrever (com o ódio, sim, e com o amor na escuta na terapia). Há os pais brancos, mas a analista também é branca, motivo de ódio inicial, mas ali o espaço "sagrado" da análise acontece (SOBRAL, 2021, p.105). E as ondas devolvem o que está agora nas margens, o corpo da criança - de novo o náufrago. E no lugar, agora, o corpo dos pais assassinados em sonho, e Cândido se sentiu "livre como nunca" mas é difícil falar, acordou com "um aperto no coração, suava muito, quase não conseguia respirar" (SOBRAL, 
2021, p.104). A terapeuta o acalma, "quero dizer que está tudo bem, tudo certo. Pode respirar aliviado" (SOBRAL, 2021, p.104).

E esse Cândido a cada dia "mais perto de si mesmo" (SOBRAL, 2021, p.104) - e esse Cândido coletivo - e singular, no seu rasgo de solidão - pode respirar, e todos que vêm com ele, a travessia de séculos, e os apagamentos, em sua dor, a cada vez, essa mancha de sangue na parede. "Expressar raiva, fúria e ódio, considerando tudo o que você passou, mesmo em um sonho ruim, é sinal de que você está cada dia mais perto de si mesmo" (SOBRAL, 2021, p.104). Entre o bem e o mal, no conto, todos são convocados na iteração do corpo em performance.

Ele nasceu de novo, e continua a nascer, como esse algo novo que deve surgir na esfera privada do lar, na adoção, e se revela em momentos do "estranho", e o que deveria permanecer oculto ao longo de séculos, em nossa sociedade brasileira, que "acolhe" e, como disse Cristiane Sobral durante o encontro, na discussão da tradução da Oficina, e recordo: sim, você diz "acolhi a criança e se sente bom para o outro, aos olhos do outro". Ora, há uma crueldade neste dizer benevolente e, também, algo que pede: você tem que ser grato. E é muito próximo do que a sociedade brasileira faz ao perpetuar um dizer que embranquece, e ordena: não diga, não revele o que deve permanecer oculto, e agradeça, ainda. $\mathrm{O}$ esquecimento do que está ali, em distinções entre esferas privada e pública que, no entanto, se comunicam (o Cândido sofre no espaço da casa e nos espaços da cidade).

Cândido já adulto, médico neurocirurgião, entra no processo de análise na terapia, lugar onde tudo pode ser dito, e se não teve o tempo do luto, o trabalho do luto, ele vive a revolta da melancolia, mas na terapia as palavras impronunciáveis têm o seu lugar. Suas identidades plurais, sua identidade em devir. Diferente do luto, na melancolia, escreve Freud, há "uma identificação do ego com o objeto abandonado", fica-se colado ao que se perdeu e há a revolta contra a perda. Em vez do trabalho de luto para dar conta do objeto perdido, lemos, em seu ensaio que, na melancolia, 
não podemos discernir com clareza o que se perdeu e com razão podemos supor que o doente também não é capaz de compreender conscientemente o que ele perdeu. Poderia ser também esse o caso de quando o doente conhece qual é a perda que ocasionou a melancolia, na medida em que de fato sabe quem ele perdeu, mas não o que perdeu nele [no objeto] (FREUD, 2011, p.29).

E “o complexo melancólico se comporta como uma ferida aberta" (FREUD, 2011, p.35). Com Freud, em Luto e Melancolia (2011), ainda que essa atitude se oponha ao trabalho de luto, de algum modo existe ali também um "trabalho". Daí a importância de ouvir esse trabalho, essa revolta, em vez de silenciar a dor, como é tendência nas sociedades modernas e contemporâneas, onde o imperativo é abafar o espaço e o tempo para o grito.

Esse ir até a outra margem como sobrevivência. E, nas margens, os restos, o que sobrou ou é devolvido pelas ondas. E o menino que sobrevive. E o menino, os meninos e meninas na diáspora, os que sobreviveram. Penso no menino que perambulava pelas ruas e é trazido para o interior da casa, e dentro da casa o seu quarto, onde era o espaço de paz, mas também onde mais apanhava do pai (SOBRAL, 2021, p.102). No sonho, Cândido tinha as chaves e entra na casa, volta ao quarto, às paredes brancas. $\mathrm{O}$ que não há no quarto: não há a mancha de sangue na parede, o seu sangue. Não está o quadro do Bob Marley, essa tinta do quadro também não está. $\mathrm{O}$ quarto branco sem cicatriz e sem a pintura, o quadro. E as frases que ouvia desde criança surgem na casa. E ouvimos, com Cândido, o som das frases que reverberam:

Estar novamente dentro da casa, era abrir essa caixa de lembranças. Saí da sala e fui direto para o meu quarto. A casa parecia mal assombrada, o único lugar de paz costumava ser o meu quarto, mas também foi ali onde eu mais apanhei (SOBRAL, 2021, p.102). 
Como se cumprir o luto? Quando não há espaço ou tempo ou reconhecimento? Lembro do fantasma em Amada, Beloved (1987), de Toni Morrison, dizendo numa língua de fragmentos o que não deveria ser dito. E os rumores da casa. A mãe que matou seu bebê para que não fosse levado pelos que os queriam escravizar, um terrível ato de amor, vingar esse amor. Sethe, fugindo da plantação para o número 124 da Bluestone Road, o território livre. Acompanhada do que sobra desse gesto, o fantasma de Amada que habitará a casa. O que deveria ter permanecido oculto, mas vem à luz. Nesse que se revela familiar e estranho, o unheimlich de Freud, que é visitado por Bhabha (1998) quando assinala em Amada as vozes que habitam a casa. Escreve Homi Bhabha:

em casas murmurantes como o número 124 da Bluestone Road, ouviremos a linguagem indecifrável dos negros mortos e raivosos, a voz da Amada de Toni Morrison, "os pensamentos das mulheres do 124, pensamentos impronunciáveis, não-pronunciados" (BHABHA, 1998, p.30).

$\mathrm{Na}$ raiva, a vontade de ser amada da fantasma, do fantasma na casa, exigência diferente das exortações de Baby Suggs em sua vocação de curar as feridas na sua comunidade de livres, em suas idas à Clareira escondida na mata, no ritual do cuidado, para o amor:

"Vocês têm de amar seu rosto, vocês! E mais: eles não gostam de nossa boca. Lá fora, irão quebrála e quebrá-la de novo. Jamais vão dar atenção às palavras e aos gritos que saem dela. O que colocamos dentro dela para nutrir nosso corpo será arrancado e substituído por restos. Não, eles não gostam de nossa boca. Estou falando de carne. Carne que precisa ser amada. Pés que precisam descansar e dançar" (MORRISON, 2007, p.107). 
Cândido, de Cristiane Sobral, no entre-lugar de seu presente, traz as dores das memórias da diáspora, e as dores de futuros projetados para fora de suas identidades possíveis. O perder-se de seus pais, e também o trauma coletivo das crianças negras que não puderam ser filhos, e o luto sem escuta na vida social, esse trauma das mães negras impedidas de serem mães de seus filhos e que não puderam viver esse luto. Darcy Ribeiro lembra que as crianças nascidas livres eram abandonadas na estrada pelos senhores, já que não teriam serventia:

Depois da primeira lei abolicionista - a Lei do Ventre Livre, que liberta o filho da negra escrava -, nas áreas de maior concentração da escravaria, os fazendeiros mandavam abandonar, nas estradas e nas vilas próximas, as crias de suas negras que, já não sendo coisas suas, não se sentiam mais na obrigação de alimentar. Nos anos seguintes à Lei do Ventre Livre (1871), fundaram-se nas vilas e cidades do estado de São Paulo dezenas de asilos para acolher essas crianças, atiradas fora pelos fazendeiros. (RIBEIRO, 2014, p. 178)

Ora, esse abandono se repete ao longo de séculos entre nós, nas formas de uma abolição que deixou à míngua as mulheres e homens escravizados, e que ao longo das décadas condena não só ao abandono mas à morte - as crianças pretas, em casa ou na rua, a caminho da escola, na barriga da mãe.

\section{Rumores na casa, riscando a cidade}

Cândido, esse peso de ter passado por tanto, traz fatos de memórias coletivas, na intimidade da casa, e ele, Cândido, se move em relação a todos que lutaram abrindo caminhos para que ele também pudesse respirar agora. Malcom X, Luís Gama, Lélia Gonzalez aparecem como suas referências 
na narrativa. A sua fúria, porém, é algo difícil de nomear. A primeira respiração, o primeiro fôlego que ele toma é para um gesto assassino: matar os pais. "Respirei fundo para tomar fôlego e bati mais, mais" (SOBRAL, 2021, p.103). No entanto, o menino Cândido de suas memórias, o menino que entrou desmaiado nos braços do vizinho que o confundiu com um ladrão no seu quintal quando ele foi brincar com o seu filho, e ele tinha doze, treze anos, esse menino que chegou desmaiado, sem ar, pelo tiro, pelo engano, "não reconheci direito", diz o vizinho, e Cândido ainda levou bronca depois da quase tragédia. Dele, lemos: "Na ocasião, ninguém fez nada. Ficou por isso mesmo. Ainda levei bronca" (SOBRAL, 2021, p.102). $\mathrm{E}$, antes disso, no início do conto, o Cândido menino que perambulava pelas ruas do mercado e termina "acolhido" na casa dos pais brancos, a mesma casa a que ele voltará adulto, o mesmo quarto, onde em meio aos objetos falta aquela única peça: o quadro de Bob Marley, o seu "espelho negro". E se ele não fez nada de errado antes foi porque "aquele que meus pais mais odiavam me salvou" (SOBRAL, 2021, p.102). O Bob Marley o ensinou a amar: "aprendi nas entrelinhas dos meus estudos médicos: ele era um virologista, com sua filosofia acreditava que poderia curar o ódio e o racismo com a música" (SOBRAL, 2021, p.102). Lembremos: Amar antes que amanheça, o título dessa obra de Cristiane Sobral.

E é na noite da casa que somos lançados juntos com Cândido no lugar fronteiriço de seu quarto da infância. De paz e de surras. O que de fato aconteceu, saberemos depois, na sessão de análise, até que ponto chegou a sua fúria. Por algum motivo ele chega atrasado no consultório da terapeuta, após a noite de seu crime, e será que ele aconteceu? Ele constrói sua fala nas sessões de terapia e ensaia dizer o impronunciável, ali ele pode falar. E é o caminho para liberar também o fardo da culpa, a "culpa carregada". Como um Candide negro, em sua ingenuidade, ele seguira a cartilha do que queriam para ele, um menino negro educado pelos brancos, brancos despreparados para isso e imersos em seus pensamentos religiosos, pais que 
"faziam o Evangelho e depois discutiam até dormir" (SOBRAL, 2021, p.97). E Cândido a cada dia começa a apreender o mundo, e é somente adulto que seu ódio vem à tona, e por um momento faz o seu céu no inferno do mundo branco, como dizem os versos do poeta jamaicano estadunidense Claude McKay (1889-1948), "my heaven in the white world's hell"2. Ecos se ouvem entre as vozes diaspóricas que falam do ódio, o ódio também como um despertar, num poema como The white city - que reescreve a cidade e desnaturaliza o programa de progresso que não o inclui no espaço desta mighty city, cidade branca, e poderosa.

$\mathrm{Na}$ terapia, novos significantes, na narrativa, esse tecido que se tece outro. Das pistas de um jogo a que Cristiane Sobral lança ao leitor, elementos do sonho.

Quando Cândido diz voltar à casa dos pais ele tem a chave e, se não tivesse arrombaria a porta, ele vê o taco de golfe, esporte que praticou - e que lhe rendeu prêmios - porque era o esporte dos brancos e era o desejo dos pais, e anuncia seu ódio, diz: "quem fez sangrar também iria sangrar" (SOBRAL, 2021, p.102). Ele mata os pais, o sangue jorrando como nas cirurgias que ele fazia em sua profissão de médico, as carnes dos açougues, o açougue do bairro (e nos perguntamos sobre mercado onde ele foi encontrado aos três anos), o sono profundo dos pais, "estavam em silêncio como eu tive que ficar todas as vezes em que apanhei" (SOBRAL, 2021, p.103). No conto, pistas, um jogo. E a revolta de Cândido se revela um sonho apenas na sessão de análise, onde ele chega atrasado. O leitor até então vai à análise com um assassino, e a desculpa que Cândido dá à terapeuta pelo atraso nesse dia ainda o incrimina diante do leitor ao mesmo tempo em que abre para a dúvida do que teria acontecido.

- Boa tarde, doutor Cândido, tudo bem?

- Tudo bem, doutora Gabriela, e com a senhora?

2 “meu céu no inferno do mundo branco" (McKAY, 1998, p.497). Tradução minha. 
- Percebi que você atrasou hoje, isso é raro. Aconteceu alguma coisa?

- Desculpa, é que acordei assustado. Nossa, tive um pesadelo terrível, sei lá, uma visão, podemos falar sobre isso? (SOBRAL, 2021, p.104)

Cristiane Sobral, em seu amor pelos personagens, nesse não julgar, avança em terrenos difíceis, subterrâneos, e diz o impronunciável. Com Cândido, somos livres para nomear o ódio e a revolta em seu corpo por séculos de sangue derramado, a violência que anuncia, por ele e por todos antes dele. E depois dele, nessa ferida do presente. Voltar à mancha de sangue na parede; escavar no branco as camadas de sangue de tempos diversos, no espaço diaspórico, neste sangue que se derrama ainda hoje; dizer o quarto, a casa, o bairro nas cidades sem lugar seguro para as identidades negras, para sua identidade, para crescer. $\mathrm{O}$ quarto, a barriga da mãe, a camisa do colégio.

E diz também o "espelho negro" de Cândido, Bob Marley, a pintura da infância, a tinta. E diz e risca a cidade e se inscreve, na fala, na escrita, ali o espaço que se abre. Na escrita, também o espaço para que algo apareça que você não diria se não começasse a caminhar sobre o papel. Nova travessia, a partir de uma construção, identidades, escurecimentos. E Cândido pode, sim, brilhar, e com manchas, ele deve brilhar, não branco ou puro, mas intenso, noite.

\section{Referências}

ALENCAR, José de. O Demônio Familiar. In: - ALENCAR, J. de. Teatro Completo. Rio de Janeiro: SNT: MEC: DAC/FUNARTE, 1977, v. 2, p.41-98.

BENJAMIN, Walter. A tarefa do tradutor. Edição e Tradução de João Barrento. In: . Linguagem, tradução, literatura (filosofia, teoria e crítica). Belo Horizonte: Autêntica, 2018, p. 87-100. A tarefa-renúncia do tradutor. Tradução de Susana Kampff Lages. 
In: BRANCO, Lucia Castello. A tarefa do tradutor, de Walter Benjamin: quatro traduções para o português. Belo Horizonte: Fale/UFMG, 2008, p.66-81.

BAKHTIN, M. Os gêneros do discurso. Tradução de Paulo Bezerra. São Paulo: Editora 34, 2016.

BHABHA, Homi K. O Local da Cultura. Tradução de Myriam Ávila, Eliana Lourenço de Lima Reis e Gláucia Renate Gonçalves. Belo Horizonte: Editora UFMG, 1998.

RIBEIRO, Darcy. O povo brasileiro: a formação e o sentido do Brasil. São Paulo: Global, 2014. . O Processo civilizatório: estudos de antropologia da civilização; etapas da evolução sociocultural. Petrópolis: Vozes, 1987.

FANON, Frantz. Pele negra, máscaras brancas. Tradução Renato da Silveira. Salvador: EDUFBA, 2008.

FARIA, João Roberto. José de Alencar e o Teatro. São Paulo: Perspectiva: Editora da Universidade de São Paulo, 1987.

FUENTES, Susana Carneiro. Os demônios familiares da leitura. 2001. Dissertação (Mestrado em Literatura Brasileira) - Instituto de Letras, Universidade do Estado do Rio de Janeiro ILE/UERJ, Rio de Janeiro, 2001.

FREUD, Sigmund. Luto e Melancolia. Tradução de Marilene Carone. São Paulo: Cosac Naify, 2011. . O "Estranho". In: Edição Standard Brasileira das Obras Psicológicas Completas de Sigmund Freud. Tradução de José Octavio de Aguiar Abreu. Rio de Janeiro: Imago, 1988. v.17, p.233-73.

MORRISON, Toni. Amada. São Paulo: Companhia das Letras, 2007.

McKAY, Claude. Poems. In: MULLANE, D. (org.) Crossing the Danger Water: three hundred years of African-American Writing. Edited and with Introduction by Deirdre Mullane. New York: Anchor Book, 1993. 
p.491-498.

NIETZSCHE, Friedrich. Genealogia da Moral: uma polêmica. Trad. Paulo César de Souza. São Paulo: Companhia das Letras, 1998.

SOBRAL, Cristiane. Amar antes que amanheça. Rio de Janeiro: Malê, 2021.

Crossings: spaces of the house and black lives

Abstract: This study, triggered out by the reading and translation process into English of the short story 'Cândido Abdellah Jr.' by Cristiane Sobral (SOBRAL, 2021), aims at analyzing the space of the house as a space of good and evil, noticing aspects of intimacy and identities portrayed in Sobral's short story. Considering, as well, questions of whiteness and the literary imagination in its casting the black man or black child out of intimacy: a gesture trying to erase singularities and differences, so to impose a superiority that reassures territories. Prejudices and punishments that have been a constant in the history of Brazilian social imagination pervades Sobral's short story, still, in a movement of giving clues, the author surprises the readers with new outcomes for Cândido, the main character in the story. In a comparative and intercultural perspective, translation has been a path to dialogue with temporalities of a diaspora, times and voices that emerge when listening to the potential noises of the text.

Keywords: Being black. Identities. Intercultural translation.

Recebido em: 19/08/2021

Aceito em: 17/09/2021 